\title{
Anna Broda
}

Wojewódzka Biblioteka Publiczna - Książnica Kopernikańska w Toruniu e-mail: a.broda@ksiaznica.torun.pl

ORCID ID: 0000-0001-7557-5122

\section{onferencje dla nauczycieli i bibliotekarzy}

„Licencja na czytanie” w Bibliotece

Pedagogicznej im. gen. bryg. prof.

E. Zawackiej w Toruniu

DOI: http://dx.doi.org/10.12775/FT.2018.016

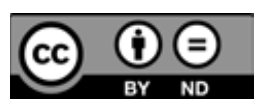

Tekst jest opublikowany na zasadach niewyłącznej licencji Creative Commons Uznanie autorstwa-Bez utworów zależnych 3.0 Polska (CC BY-ND 3.0 PL).

Mgr Anna Broda jest pracownikiem Działu Informacyjno-Bibliograficznego Wojewódzkiej Biblioteki Publicznej - Książnicy Kopernikańskiej w Toruniu. Zajmuje się opracowywaniem formalnym i rzeczowym Bibliografii woj. kujawsko-pomorskiego (region toruńsko-włocławski) oraz Dorobku pracowników WBP-KK.

łowa kluczowe: czytelnictwo; ruch wydawniczy; konferencja; bibliotekarze; nauczyciele; Biblioteka Pedagogiczna w Toruniu

treszczenie. Od 2016 r. w Bibliotece Pedagogicznej w Toruniu odbywają się konferencje z cyklu „Licencja na czytanie”. Spotkania skierowane są do bibliotekarzy i nauczycieli, zainteresowanych kwestiami edukacji czytelniczej, promocji czytelnictwa i zagadnień wydawniczych. Naukowcy, nauczyciele, księgarze, pisarze, ludzie kultury opowiadają o swoich doświadczeniach, dzielą się wiedzą, omawiają wyniki badań i na ich podstawie prognozują przyszłość czytelnictwa. Wystąpieniom towarzyszą warsztaty, zabawy literackie i konkursy.

Od trzech lat w Bibliotece Pedagogicznej w Toruniu odbywają się konferencje „Licencja na czytanie”, skierowane do bibliotekarzy i nauczycieli, którzy co roku spotykają się, by dyskutować o bieżących sprawach nurtujących te grupy zawodowe1.

\footnotetext{
Tekst powstał w oparciu o trzy wpisy autorki na blogu Informatorium.ksiaznica.torun.pl: [A. Broda], Relacja z konferencji - „Licencja na czytanie”, [w:] Informatorium. Blog Działu Informacyjno-Bibliograficznego Wojewódzkiej Biblioteki Publicznej - Książnicy Kopernikańskiej w Toruniu [online], [dostęp 25 IV 2018]. Dostępny w World Wide Web: http://informatorium.ksiaznica.torun.pl/relacja-konferencji-licencja-czytanie/; [eadem], Konferencja „Licencja na czytanie II", [w:] ibidem, [dostęp 25 IV 2018]. Dostępny w World Wide Web: http://informatorium.ksiaznica. torun.pl/konferencja-licencja-na-czytanie-ii/; [eadem], Licencja na czytanie III - Od autora do czytelnika, czyli od „produkcji” do „konsumpcji”, [w:] ibidem, [dostęp 25 IV 2018]. Dostępny w World Wide Web: http://informatorium. ksiaznica.torun.pl/licencja-na-czytanie-iii-od-autora-do-czytelnika-czyli-od-produkcji-do-konsumpcji/.
} 
Pierwsza edycja, dotycząca czytelnictwa dzieci i młodzieży, odbyła się 14 kwietnia 2016 r. Słowo wstępne wygłosiła dyrektor Biblioteki Pedagogicznej Elżbieta Wykrzykowska. Pierwsza prelegentka, dr Elżbieta Kruszyńska z Instytutu folia Literatury Polskiej UMK, opowiedziała o powieściach dla dziewcząt w dwudziestoleciu międzywojennym. W wystąpieniu „Od grzecznej pensjonarki do dzikuski i chłopczycy - powieść dla dziewcząt w XX-leciu międzywojennym” wyróżniła w nich trzy grupy: 1) romans sentymentalny, 2) romans dydaktyczny, 3) powiastka dydaktyczno-moralizatorska.

Do cech charakterystycznych tego gatunku zaliczyła: dziewczęta w wieku 12-16 lat jako adresatki; bohaterkę - dziewczynkę w wieku dorastania; nasycenie problematyką moralną i obyczajową; język i styl jasny i prosty, brak żargonu młodzieżowego, za to wiele zdrobnień; schematyczne, obowiązkowo szczęśliwe zakończenie.

Za pierwszą polską autorkę powieści dla dziewcząt uznaje się Klementynę z Tańskich Hoffmanową, twórczynię m.in. Pamiątki po dobrej matce, O moralności kobiet, Dziennika Franciszki Krasińskiej. Referentka wyróżniła trzy nurty powieści dla dziewcząt: psychologiczno-pedagogiczny, narodowy i obywatelsko-państwowy oraz demokratyczny. Osobną grupę stanowiły książki zakazane dla dziewcząt, które były jednocześnie przez nie najchętniej czytane. Komisja Oceny Książek zaopiniowała w ten sposób m.in. książki Marii Rodziewiczówny, Heleny Mniszkówny, Stanisława Przybyszewskiego czy Lidii Czarskiej.

Czytelnictwo w dwudziestoleciu międzywojennym kształtowało się na wysokim poziomie. Wpływ miała na to jego promocja w szkołach, licznie powstające wydawnictwa i bogate w zbiory biblioteki.

Beata Bielska z Zespołu Realizacji Badań Pryzmat przedstawiła raport z badań przeprowadzonych w szkołach ponadgimnazjalnych Torunia - „CzytaNIE - czy uczniowie toruńskich szkół ponadgimnazjalnych sięgają po książki?”. Ankietą audytoryjną objęto klasy drugie szkół dziennych. Łącznie przebadano 334 uczniów, z których $22 \%$ okazało się aktywnymi czytelnikami, a 21\% przyznało, że w ogóle nie sięga po książki. Prelegentka omówiła szczegółowo wyniki badań czytelnictwa wśród uczniów z uwzględnieniem tła społecznego i socjologicznego. Podkreśliła, że ważny wpływ na zainteresowania czytelnicze w okresie dorastania mają rówieśnicy, a także częstotliwość obcowania z literaturą od wczesnego dzieciństwa.

Po przerwie głos zabrała Elżbieta Ciesielska z Gimnazjum nr 24 w Toruniu. Zrelacjonowała przebieg konkursu „Gwiazdorskie lektury”. Wzięli w nim udział uczniowie klas trzecich gimnazjum. Teksty zadań konkursowych dotyczyły Trenów Jana Kochanowskiego, Bajek Ignacego Krasickiego, Zemsty Aleksandra Fredry i wybranej powieści Henryka Sienkiewicza. Następnie Katarzyna Fiałkowska z I Liceum Ogólnokształcącego w Toruniu opowiedziała o odpowiedniku tego konkursu w szkołach ponadgimnazjalnych. Uczestniczyli w nim uczniowie trzecich klas, zadania zaś poświęcone były m.in. Lalce Bolesława Prusa, Panu Tadeuszowi Adama Mickiewicza i Ferdydurke Witolda Gombrowicza.

Ewa Stanek z księgarni Bookinista w wystąpieniu „Trendy czytelnicze wśród dzieci i młodzieży z perspektywy księgarza" zaprezentowała książki, które kupowane 
są w Bookiniście najczęściej, zapoznała uczestników konferencji z najpopularniejszymi cyklami wydawniczymi w poszczególnych grupach wiekowych. Opowiedziała o wydawnictwach, które mogą być interesujące dla młodego czytelnika i zachęcą go do dalszych poszukiwań literackich.

Kolejny referat „Czytam aby ŻYĆ” Marii Jadczak, nauczycielki historii z Gimnazjum i Liceum Akademickiego w Toruniu, poświęcony został samemu zjawisku czytania. Autorka przedstawiła badania psychologiczne i neurologiczne, które dowodzą wpływu czytania na uruchamianie konkretnych partii mózgu. Wiedza jest synonimem władzy, dlatego wielokrotnie w dziejach rządzący tworzyli indeksy ksiąg zakazanych. Czytanie jest niezwykle istotne dla rozwoju osobistego, uruchamia wyobraźnię, pozwala żyć podwójnie i poszerza horyzonty myślowe.

Michał Żarski, polonista z I Liceum Ogólnokształcącego w Toruniu, w wystąpieniu „Okiem blogera. Spojrzenie na literaturę” omówił dwa prowadzone przez siebie blogi: LiteraTura oraz MichelJarre. Zamieszczane są na nich recenzje książek, eseje, przemyślenia. Bardziej rozbudowany i częściej uzupełniany jest blog LiteraTura. Znajdują się tu recenzje muzyczne (głównie muzyka metalowa) oraz literackie (rzadziej beletrystyka, przede wszystkim literatura faktu). Blog ten może być źródłem dodatkowej wiedzy dla młodzieży szkolnej, zwłaszcza w zakresie historii najnowszej i reportażu.

Na koniec Anita Streich i Hanna Wrycza-Wilińska, przedstawicielki Zespołu Szkół Gastronomiczno-Hotelarskich w Toruniu, opowiedziały o swoich doświadczeniach z programu Erasmus, a także quizach jako metodzie promocji czytelnictwa. Spotkanie finalizowało projekt "Czytaj od A do Zachwytu”, przygotowany i realizowany w Bibliotece Pedagogicznej w Toruniu.

Druga odsłona konferencji odbyła się 25 kwietnia 2017 r. „Licencji na czytanie II" towarzyszyły warsztaty z komunikacji literackiej, mające pomóc uczestnikom w doskonaleniu umiejętności pisania recenzji. Spotkanie otworzyła i poprowadziła Dorota Komendzińska, dyrektor Biblioteki Pedagogicznej. Pierwszy referent, dr hab. Maciej Wróblewski z Instytutu Literatury Polskiej UMK w wystąpieniu „..._.Piszę __czytamCzytam-_Piszę_Czytam - _... Między tradycyjnymi a nowymi wzorami czytania literatury" przedstawił badania, których przedmiotem jest zagadnienie czytelnictwa wśród młodzieży i studentów. Powołując się na badania Biblioteki Narodowej z lat 1994-2015, omówił postępujący proces spadku czytelnictwa w Polsce. Prelegent wysunął tezę, że współcześnie młodzi ludzie czytają coraz mniej uważnie, bardziej skanują tekst, niż wnikają w jego sens. W ciągu ostatnich szesnastu lat zmienił się charakter tekstów - nie korzysta się z ksiąg, czyli ciągu tekstowego, ale z tekstów poczłonkowanych, nasyconych znakami graficznymi. Użytkownicy często nie potrafią skupić się na tekście rozbudowanym i wysokoartystycznym. Studenci coraz rzadziej korzystają z książek drukowanych, zastępując je tekstami czytanymi na urządzeniach elektronicznych, np. czytnikach czy smartfonach.

Dr Emilia Kubicka z Instytutu Języka Polskiego UMK w „Elektronicznych dziełach leksykograficznych - nowym wymiarze pracy ze słownikiem" omówiła słowniki języka polskiego dostępne on-line i oczekiwania, jakie według użytkowników Internetu powinny one spełniać (wiarygodność treści, jasność opisu lek- 
sykograficznego, aktualność zawartości, szybkość pracy programu i możliwość długotrwałego dostępu). Do zalet słowników elektronicznych dr Kubicka zaliczyła: nielimitowaną objętość, szybki dostęp do danych, możliwość kopiowania do innych aplikacji, zaawansowane systemy wyszukiwania i bieżącą aktualizację (w tym możliwość poprawienia błędów). Za wadę słowników elektronicznych prelegentka uznała fakt, że wymagają dostępu do Internetu lub zainstalowania oprogramowania, często tworzone są komercyjnie, przez co bywa, że szybko i przez osoby, które nie mają kompetencji leksykograficznych. Następnie referentka omówiła trzy słowniki dostępne on-line: Wielki słownik języka polskiego PAN [wsjp.pl] (który współtworzy), Słownik języka polskiego PWN [sjp.pwn.pl] i Dobry słownik [dobryslownik. pl]. Słownik PAN-owski dostępny jest wyłącznie on-line, powstaje dzięki grantom, jest słownikiem nienormatywnym, zawiera definicje wyrażeń, system powiązań i odsyłaczy między hasłami, informacje o łączliwości oraz datę ostatniej aktualizacji. Słownik języka polskiego PWN jest połączeniem Słownika języka polskiego pod redakcją Witolda Doroszewskiego, Słownika języka polskiego Mieczysława Szymczaka, słownika synonimów i ortograficznego. Nie jest godny polecenia, gdyż jest słownikiem komercyjnym i nie do końca sprawdzonym, nie ma osoby za niego odpowiedzialnej. Dobry słownik jest oparty na tekstach kultury, a nie na starych słownikach. Jest to ciekawa baza, zwłaszcza ze względu na prowadzony tu blog z artykułami poprawnościowymi.

Po przerwie głos zabrał dr hab. Marcin Wołk z Instytutu Literatury Polskiej UMK. W referacie „Proza polska po roku 1989 - krótkie wprowadzenie” przedstawił podział literatury XX i XXI wieku oraz nazewnictwo poszczególnych okresów: 1) 1918-1939 - literatura międzywojenna, 2) 1939 (1945)-1989 - literatura współczesna, 3) od 1989 r. - literatura najnowsza. Niektórzy badacze początek literatury najnowszej datują na rok 1976, utożsamiają go z drugim obiegiem. Bardziej rozpowszechniony jest jednak, jako data graniczna, 1989 - rok zmian geopolitycznych, ustrojowych i gospodarczych. Zmieniła się wówczas ranga literatury, nastąpiło otwarcie na świat. Cenieni pisarze często nie potrafili odnaleźć się w nowej rzeczywistości i nie umieli jej opisać. Na ten czas przypada debiut literacki, m.in. Pawła Huelle, Jerzego Pilcha, Andrzeja Sapkowskiego, Manueli Gretkowskiej, Andrzeja Stasiuka, Olgi Tokarczuk czy Stefana Chwina. Dr Wołk wyróżnił następujące tendencje w literaturze po 1989 r: 1) małe ojczyzny, literatura prowincji, 2) mitologizacja codzienności, 3) postmodernizm, 4) intertekstualność, 5) feminizm, gender, 6) dole i niedole transformacji, 7) ruchome marginesy (zanik granic w sferze etyki i estetyki).

Marta Baszewska wystąpienie „Dialog słowa i obrazu. Picture book pod lupą" rozpoczęła od zdefiniowania książki obrazkowej/ obrazowej. Do jej cech charakterystycznych zaliczyła: 1) ikonotekst - niepodzielność słowa i obrazu, 2) parateksty - wszystkie dodatkowe elementy książki poza tekstem i obrazem (np. format), 3) hybrydowość gatunkową 4) brak ujednolicenia nazwy, 5) artystyczną formę, 6) całościowość autorskiego projektu (dzieło kongenialne), 7) czytelnik = współautor, 8) tematykę ważną społecznie (otwarcie się na Innego), 9) przeciwwagę wobec kiczu i infantylizacji, 10) traktowanie dziecka jako podmiotu, partnera, 11) wielopoziomowość i mnogość interpretacji, 12) brak moralizatorstwa i charakteru 
dydaktycznego. Picture book to nie książka ilustrowana. Najważniejsza między nimi różnica polega na tym, że w książce ilustrowanej tekst może istnieć bez ilustracji, w przypadku picture booków tekst i obraz są ze sobą ściśle powiązane i nie mogą funkcjonować samodzielnie. Picture booki z komiksem wiąże jedność słowa i obrazu, wiele różni jednak te gatunki literackie, choćby narracyjność komiksu, której picture book jest pozbawiony. Sami teoretycy literatury mają trudności w zdefiniowaniu, co jest książką obrazową. Prelegentka podała najprostszą metodę identyfikacji: jeżeli istnieje trudność w zrozumieniu tekstu bez obrazu i odwrotnie, oznacza to, że mamy do czynienia z picture bookiem. Jedną z najbardziej znanych autorek książek obrazowych jest Iwona Chmielewska, która tworzy ilustracje do tekstów innych autorów. W swoich pracach operuje awersem i rewersem strony, kompozycją otwartą, dziecięcą wyobraźnią, zabiegami wywołującymi silne stany emocjonalne i zaskakującymi czytelnika.

Ostatni referat „Siła i nadzieja”? - kobiece biografie w komiksach o tematyce lagrowej" wygłosiła dr hab. Barbara Czarnecka z Uniwersytetu Jagiellońskiego. W ostatnich latach doceniono siłę oddziaływania komiksu, obecnie często bywa on orędziem walki propagandowej i łatwą metodą osiągnięcia zysków. Bywają publikacje dobrze udokumentowane historycznie i te mogą odgrywać niezwykle cenną rolę w popularyzacji historii. Sporo powstaje jednak komiksów o miernej jakości i jednoznacznie ukierunkowanych politycznie. Twórcami komiksów są głównie mężczyźni, w tym referentka upatruje przyczyn stylizowania kobiet na pin-up-girls i faktu, że opowieści te są przeważnie męską wersją kobiecej historii. Prelegentka omówiła kilka wybranych komiksów, m.in. Siłę i nadzieję. Dziewczęta z Ravensbrück. Obóz ten był pierwszym obozem dla kobiet, miał być obozem „modelowym”, przeszło przez niego ok. 130 tys. kobiet. Publikację tę dr Czarnecka uznała za nieudaną próbę wprowadzenia kobiecej historii do komiksowej stylistyki. Do mankamentów zaliczyła współczesne stroje bohaterek i nieklarowność niektórych obrazów oraz wydarzeń. Kobiety w Ravensbrück poddawane były wielu eksperymentom medycznym, niestety autorki komiksu z tym tematem również sobie nie poradziły, potraktowały go sztampowo i w sposób konwencjonalny.

Podsumowania konferencji dokonała Katarzyna Fijałkowska z Toruńskiego Ośrodka Doradztwa Metodycznego i Doskonalenia Nauczycieli.

Po zakończeniu obrad rozpoczęły się warsztaty. Uczestnicy mieli do wyboru następujące tematy:

- „Jak pisać recenzje? Warsztaty z elementami webwritingu” - Paulina Matysiak, autorka bloga „Zaginam Rogi”

- "Monolog i dialog w „Lubiewie” Michała Witkowskiego” - dr hab. Marcin Wołk, UMK

- „Trening kreatywności, czyli co ma wiatrak do piernika...” - dr Magdalena Cyrklaff, UMK

„Licencja na czytanie III” przebiegała pod hasłem „Od autora do czytelnika, czyli od „produkcji” do „konsumpcji” i poświęcona została obecnemu stanowi rynku wydawniczego oraz czytelnictwu w Polsce. 
W programie imprezy, która odbyła się 11 kwietnia 2018 r., znalazły się cztery wystąpienia, reprezentujące odpowiednio środowisko naukowe, autorskie, blogerskie (mediów społecznościowych) i promocyjne.

Jako pierwsza z referatem „Zmierzch książki?” wystąpiła dr hab. Wanda A. Ciszewska z Uniwersytetu Mikołaja Kopernika w Toruniu. Prelegentka rozpoczęła od podania statystyk. $Z$ analizy danych z ostatnich dziesięciu lat wynika, że nakłady książek maleją z roku na rok. Do problemów rynku wydawniczego dr Ciszewska zaliczyła: wzrost cen książek związany z wprowadzeniem 5\% VAT-u w 2011 r.; błędy zakupowe w 2013 r. - zostało zamówionych zbyt dużo książek, które potem zwrócono do wydawnictw; wprowadzenie przez Ministerstwo Edukacji Narodowej darmowych podręczników w 2014 r.; spadki sprzedaży tradycyjnej na rzecz internetowej oraz zmniejszenie się liczby księgarń stacjonarnych.

W 2014 r. pojawił się projekt Ustawy o jednolitej cenie książki. Zakładał m.in. stałą cenę książki, która miałaby obowiązywać przez dwanaście pierwszych miesięcy; karę grzywny za naruszenie Ustawy; rabaty dopuszczalne jedynie w określonych przypadkach, np. na targach książki. Lobbowanie na rzecz Ustawy trwa już czwarty rok, prace nad nią wznowiono w 2017 r., ale w dalszym ciągu nie przyjęto żadnych rozstrzygnięć.

Obecnie funkcjonuje w Polsce 1800 księgarń, te niezależne stanowią większość. Największą siecią księgarską jest Empik, dysponujący około 70 tys. tytułów. Wielokrotnie w przeciągu ostatnich kilku lat były organizowane akcje, mające zwrócić uwagę na monopolistyczne praktyki sieci, prowadzące do finansowych kłopotów małych wydawnictw.

Książka elektroniczna to alternatywa dla tradycyjnych form wydawniczych. Większość czytających na czytnikach bądź na innych urządzeniach mobilnych to osoby w przedziale wiekowym 25 - 44. Użytkownicy czytników czytają statystycznie znacznie więcej niż czytelnicy książek papierowych. Największym problemem związanym z e-bookami jest ich wysoka cena, na którą wpływ ma w dużej mierze $23 \%$ VAT (e-book traktowany jest jako usługa elektroniczna).

Karina Obara w rozmowie z Robertem Małeckim, toruńskim pisarzem, zatytułowanej „Udręki i ekstazy, czyli jak zacząć pisać powieść i ją skończyć”, zastanawiała się, jak wygląda proces twórczy autora kryminałów. Literat w ciągu dwóch ostatnich lat wydał trzy książki. Pierwsza powieść, która wyszła spod pióra Roberta Małeckiego, nigdy się nie ukazała, mimo że została wysłana do wielu wydawnictw. Autor stwierdził, że sam uważa ją za naprawdę złą, choć w momencie, kiedy powstała uznał, iż wzniósł się na wyżyny powieściopisarstwa. Opowiedział o swoim dniu pracy, o rozpisywaniu pomysłu na sceny, poszczególne etapy, które następnie doskonali i rozbija na czynniki pierwsze. Podzielił się z uczestnikami swoimi wątpliwościami, zachwytami i problemami, z jakimi się boryka. Samo pisanie jest bardziej udręką niż ekstazą, ale uznanie czytelników wynagradza wszystkie męki, jakie towarzyszą autorowi w procesie tworzenia.

Po przerwie głos zabrał Maksymilian Lawera, który w referacie „Wydawnictwo od kuchni. Od redakcji do promocji” omówił działalność Grupy Wydawniczej Foksal. Jest ona połączeniem wydawnictw: W.A.B, Buchmann i Wilga. W 2013 r. 
dołączyły do nich również YA!, Uroboros i FoxGames. Referent przedstawił strukturę wydawnictwa oraz funkcje, jakie pełnią poszczególne działy. Maksymilian Lawera związany jest z działem promocji, dlatego właśnie tej komórce poświęcił większą część wystąpienia. Opowiedział o metodach reklamowania produktów, zarówno w tradycyjnych mediach, jak i płatnych kampaniach na portalach społecznościowych, mechanizmach reklamy internetowej i relacjach wydawnictw z blogerami i volgerami, którzy otrzymują książki w zamian za ich zrecenzowanie i promocję.

Rafał Hetman, twórca bloga CzytamRecenzuję, przedstawił swoją drogę do sukcesu. Autor, gdy zaczynał przygodę z mediami społecznościowymi, pracował zawodowo, wieczory poświęcał na zamieszczanie wpisów i filmików z recenzjami przeczytanych książek. Z czasem zyskał taką popularność i uznanie, iż mógł poświęcić się jedynie prowadzeniu bloga. Dziś dzień zaczyna od przejrzenia maili, ich selekcji i odpowiedzenia na interesujące propozycje wydawnictw, negocjuje umowy i umawia się na spotkania. Nie pobiera opłat za recenzje książek, gdyż nie chce być skrępowany finansami i uznany za nieobiektywnego. Zarabia na płatnych promocjach, np. akcjach „szukania książek”, konkursach i różnego typu eventach organizowanych na Facebooku czy Instagramie. Prelegent zwrócił uwagę na dwie rzeczy, które są kluczem do sukcesu blogera: systematyczność (tylko bardzo regularne zamieszczanie wpisów i filmików daje gwarancję przyciągnięcia, utrzymania oraz stałego poszerzania grona obserwatorów) i korzystanie z wielu kanałów („trzeba być jednocześnie wszędzie” - na FB, Instagramie, YouTubie, Twitterze itp.).

Ostatnim mówcą był Łukasz Wudarski z Centrum Kultury Dwór Artusa w Toruniu. Na początku referatu „Jak promować literaturę w czasach, gdy nikt nie czyta” zaznaczył, iż proces szukania sposobów na zwiększenie czytelnictwa zacząć należy od przeanalizowania statystyk, aby odnaleźć pewne reguły i wyciągnąć odpowiednie wnioski. Książek, według najnowszych badań Biblioteki Narodowej, nie czyta około $60 \%$ Polaków, a tylko 10\% przeczytało więcej niż siedem tytułów w ciągu roku.

Łukasz Wudarski na przykładzie Dworu Artusa przedstawił, jak może wyglądać promocja czytelnictwa na przestrzeni lat i jakie kroki podejmuje się, aby zainteresowanie imprezami o charakterze kulturalnym z roku na rok wzrastało. Jeszcze w latach 90 . XX w. na spotkania autorskie przychodziły tłumy, często frekwencja przekraczała trzysta osób. W kolejnych sezonach nawet bardzo znane nazwiska nie były w stanie przyciągnąć połowy dotychczasowej widowni. Zlecono zatem badania fokusowe, przeprowadzono liczne ankiety, które miały kluczowy wpływ na dalszą strategię postępowania. Po ich przeanalizowaniu wprowadzono zmiany w sposobie, terminach i miejscach organizacji poszczególnych wydarzeń, np. Toruński Festiwal Książki przeniesiono na miesiące letnie, a same spotkania z czytelnikami zaaranżowano w różnorodnych plenerach. Prelegent za najważniejszą rzecz uznał pomysł. To on, wsparty odpowiednimi działaniami promocyjnymi, da organizatorom sukces. Wyjście do ludzi, urozmaicanie form kulturalnych (np. spotkanie autorskie nie jako monolog powieściopisarza, lecz jako panel dyskusyjny kilku twórców kryminałów lub powieści historycznych), współpraca z innymi instytucjami czy umiejętne zaistnienie w mediach społecznościowych, to doskonałe formy dotarcia do odbiorców. Niezwykle istotna jest także edukacja przyszłych 
uczestników życia kulturalnego, poprzez np. warsztaty literackie, spotkania dla młodzieży, imprezy czytelnicze dla dzieci.

Dyrektor Dorota Komendzińska podsumowała przebieg obrad i przyznała, że z zainteresowaniem wysłuchała wszystkich wystąpień, a z wielu ciekawych pomysłów na promocję czytelnictwa Biblioteka Pedagogiczna na pewno w przyszłości skorzysta. Na koniec rozlosowano wśród zebranych książki wydawnictwa W.A.B.

Cykl „Licencja na czytanie” to inicjatywa ciekawa, przemyślana i spójna. Spotykają się tu teoretycy i praktycy, którzy wymieniają swoje doświadczenia oraz dzielą się z uczestnikami wiedzą, umiejętnościami i kompetencjami. Niesłabnące zainteresowanie bibliotekarzy i nauczycieli świadczy o powodzeniu tego przedsięwzięcia. Z roku na rok impreza wzbogacana jest o nowe wydarzenia towarzyszące: w 2017 r. były to warsztaty, w 2018 r. - cykl ćwiczeń praktycznych „A może spróbujmy inaczej?", a także zabawa literacka związana z Robertem Małeckim oraz testy ze znajomości publikacji Wydawnictwa W.A.B., Biblioteki Pedagogicznej oraz reportażu. Po zakończeniu spotkań do ich uczestników rozsyłana jest anonimowa ankieta elektroniczna, w której ocenie podlega zarówno strona merytoryczna, jak i formalna konferencji.

\section{Bibliografia}

[Broda, Anna]. 2016. „Relacja z konferencji - „Licencja na czytanie”.” Informatorium. Blog Działu Informacyjno-Bibliograficznego Wojewódzkiej Biblioteki Publicznej - Książnicy Kopernikańskiej w Toruniu. Ostatnia modyfikacja Kwiecień 26. http://informatorium.ksiaznica.torun.pl/relacja-konferencji-licencja-czytanie/.

[Broda, Anna]. 2017. „Konferencja „Licencja na czytanie II”.” Informatorium. Blog Działu Informacyjno-Bibliograficznego Wojewódzkiej Biblioteki Publicznej Książnicy Kopernikańskiej w Toruniu. Ostatnia modyfikacja Kwiecień 28. http:// informatorium.ksiaznica.torun.pl/konferencja-licencja-na-czytanie-ii/.

[Broda, Anna]. 2018. „Licencja na czytanie III - Od autora do czytelnika, czyli od „produkcji” do „konsumpcji”.” Informatorium. Blog Działu Informacyjno-Bibliograficznego Wojewódzkiej Biblioteki Publicznej - Książnicy Kopernikańskiej w Toruniu. Ostatnia modyfikacja Kwiecień 28. http://informatorium.ksiaznica.torun. pl/licencja-na-czytanie-iii-od-autora-do-czytelnika-czyli-od-produkcji-do-konsumpcji/.

Przysłany: 10 V 2018

Zaakceptowany: 5 VII 2018 


\section{Anna Broda}

Nicolaus Copernicus Public Provincial Library in Toruń e-mail: a.broda@ksiaznica.torun.pl

ORCID ID: 0000-0001-7557-5122

Anna Broda, MA, is an employee of the Information and Bibliographic Department of the Nicolaus Copernicus Public Provincial Library in Torun. She deals with the formal and material development of the Bibliography of the Kuyavian-Pomeranian Province (Toruń-Włocławek region) and the Work of NCPPL employees.

\section{Conferences for teachers and librarians}

\section{„Licencja na czytanie” [License for reading]} in the Pedagogical Library under the name of Brigadeer General Profesor E. Zawacka in

\section{Toruń}

DOI: http://dx.doi.org/10.12775/FT.2018.016

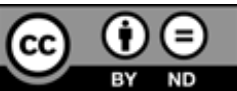

The text is available under a Creative Commons Attribution-NoDerivatives 3.0 Poland (CC BY-ND 3.0 PL).

eywords: reading; publishing movement; conference; librarians; teachers; Pedagogical Library in Toruń

ummary: Since 2016, conferences from the License for reading series have been held at the Pedagogical Library in Toruń. Meetings are addressed to librarians and teachers interested in issues of reading education, promotion of reading and publishing issues. Researchers, teachers, booksellers, writers, and people of culture talk about their experiences, share knowledge, discuss research findings and predict the future of reading on their basis. The performances are accompanied by workshops, literary games and competitions. 


\section{Anna Broda}

Öffentliche Woiwodschaftsbibliothek - Kopernikus Bücherei in Toruń e-mail: a.broda@ksiaznica.torun.pl

Mag. Anna Broda ist Mitarbeiterin der Informations- und Bibliografischen Abteilung der Öffentliche Woiwodschaftsbibliothek - Kopernikus Bücherei in Toruń. Sie beschäftigt sich mit der Formal- und Sachbearbeitung der Bibliografia woj. kujawsko-pomorskiego (region toruńsko-włocławski) [Bibliografie der Kujawsko-Pomorskie Wojewodschaft (Region Toruń - Włocławek)] und Dorobku pracowników WBP-KK [Bibliografie der Publikationen der Mitarbeiter der Öffentliche Woiwodschaftsbibliothek - Kopernikus Bücherei in Toruń].

\section{Tagungen für Lehrer und Bibliothekare „Licencja na czy tanie” [Lizenz für Lesen] in der Pädagogischen Elżbieta-Zawacka-}

\section{Bibliothek in Toruń}

DOI: http://dx.doi.org/10.12775/FT.2018.016

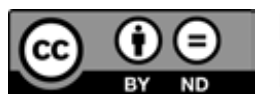

Dieser Text wird unter der Creative Commons-Lizenz Namensnennung-Keine Bearbeitung Polen (CC BY-ND 3.0 PL) veröffentlicht.

tichworte: Lesen; Verlagsbewegung; Tagung; Bibliothekare; Lehrer; Pädagogische Bibliothek in Toruń

usammenfassung. Seit 2016 finden in der Pädagogischen Bibliothek in Toruń Tagungen aus der Reihe „Lizenz für Lesen“, die an die Bibliothekare und Lehrer, welche an der Leserbildung, der Popularisierung des Lesens und der Verlagsfragen interessiert sind, gerichtet werden. Die Forscher, Lehrer, Buchhändler, Schreiber, Leute der Kultur berichten über ihre Erfahrungen, teilen Wissen, besprechen ihre Forschungsergebnisse, anhand deren sie die Zukunft der Lesekultur bestimmen. Die Vorträge werden durch Werkstätte, literarische Spiele und Wettbewerbe begleitet. 